\title{
Socio-economic Profile of the Small-scale Dive Fishery in the Commonwealth of Puerto Rico
}

\author{
JUAN J. AGAR and MANOJ SHIVLANI
}

\section{Introduction}

Commercial diving is the fastest growing and most valuable fishery in the Commonwealth of Puerto Rico (Fig. 1). Its share of landings rose from $14 \%$ in 1994 to $31 \%$ in 2014 , while its share of revenues increased from $19 \%$ to $39 \%$ during the same period (NMFS, 2016). In 2014, divers reported harvesting slightly less than half a million pounds of shellfish and finfish with a dockside value of $\$ 2.3$ million (NMFS, 2016).

The lure of commercial diving lies in its high earning potential and ease of entry. Divers can selectively target a diverse group of highly valued species such as queen conch, Strombus gigas; spiny lobster, Panulirus argus; miscel-

Juan J. Agar is with the Social Science Research Group, Southeast Fisheries Science Center, National Marine Fisheries Service, NOAA, Miami, FL 33149 (email:Juan.Agar@noaa.gov), and Manoj Shivlani is with the Department of Marine Ecosystem and Society, University of Miami (RSMAS), Miami, FL 33149.

doi: dx.doi.org/10.7755/MFR.78.3-4.2 laneous reef-fish (Labridae, Scaridae, Lutjanidae); and octopus (Octopodidae) with modest capital investments in craft and fishing equipment. ${ }^{1}$ Moreover, scuba equipment can be readily serviced around the island (ValdésPizzini, 1992).

In addition to low capital requirements, year-round warm weather and accessible facilities further encourage this activity (Valdés-Pizzini ${ }^{2}$ ). Additionally, divers do not face catch and gear theft problems associated with other fishing gears such as traps (Agar et al., 2008). However, they face greater health risks due to the potential for decompression sickness (bends), embolism, and shark encounters. Repetitive dives increase the incidence of bone necrosis, paralysis, and

${ }^{1}$ In 2014, queen conch, spiny lobster, hogfish (Labridae), and octopus accounted for $42 \%$, $40 \%, 5 \%$, and $4 \%$ of the dockside revenues derived from diving, respectively (NMFS, 2016).

${ }^{2}$ Valdés-Pizzini, M. 2006. Trajectory of fishing gears in Puerto Rico: technological changes in local fisheries. Prelim. rep. submitted to the NMFS Southeast Fisheries Science Center, Miami, Fla., 51 p.

counted for about $61 \%$ of the nonlabor variable costs. Most of the crew members were non-kin because of the hazardous nature of diving which favors recruitment decisions based on skill and compatibility rather than kinship relationships. However, fishermen reported that diving accidents were not rare occurrences. Economic pressures and operational carelessness (rather than ignorance about diving risks) were cited as the main factors behind the accidents. Fishermen exhibited a high degree of occupational fidelity. Income sharing arrangements between boat owners and crew were found to be fairly egalitarian. The article underscores the need to explicitly consider safety at sea concerns when assessing the impact of management proposals. even death (Matos-Caraballo and Torres Rosado, 1989; González-Román, 1991; Lopez-Tristani et al., 2004).

In recent decades, fishery managers have become increasingly concerned about the health of queen conch, spiny lobster, and reef-fish populations in Puerto Rico, prompting them to adopt a number of regulations that included catch quotas, trip limits, seasonal and area closures, size limits, and miscellaneous gear restrictions. Surprisingly, little socio-economic research has been conducted on the dive fishery which is responsible for almost all of the queen conch revenues and close to $60 \%$ of the spiny lobster revenues (NMFS, 2016). ${ }^{3}$ Moreover, the queen conch stock continues to be overfished. This paper describes the economic and social conditions of the commercial dive fishery to assist with policy development and evaluation. To the best of our knowledge, this study offers the first comprehensive view of the commercial dive fishery in Puerto Rico.

\section{Methods}

The data used in this study was derived from in-person interviews with commercial divers (hereafter "divers") and key informants, and secondary data sources which included governmental reports and databases. In total, we conducted 81 personal interviews with divers, which is over one-third (37\%) of the population of "active" divers who report landings statistics (Table 1). ${ }^{4}$

\footnotetext{
${ }^{3}$ The salient exception is Valdés-Pizzini (1992); however, his work focused mainly on the west coast of Puerto Rico.

${ }^{4}$ The sampling frame consisted of divers who reported landings at least once between 2011 and 2013.
} 

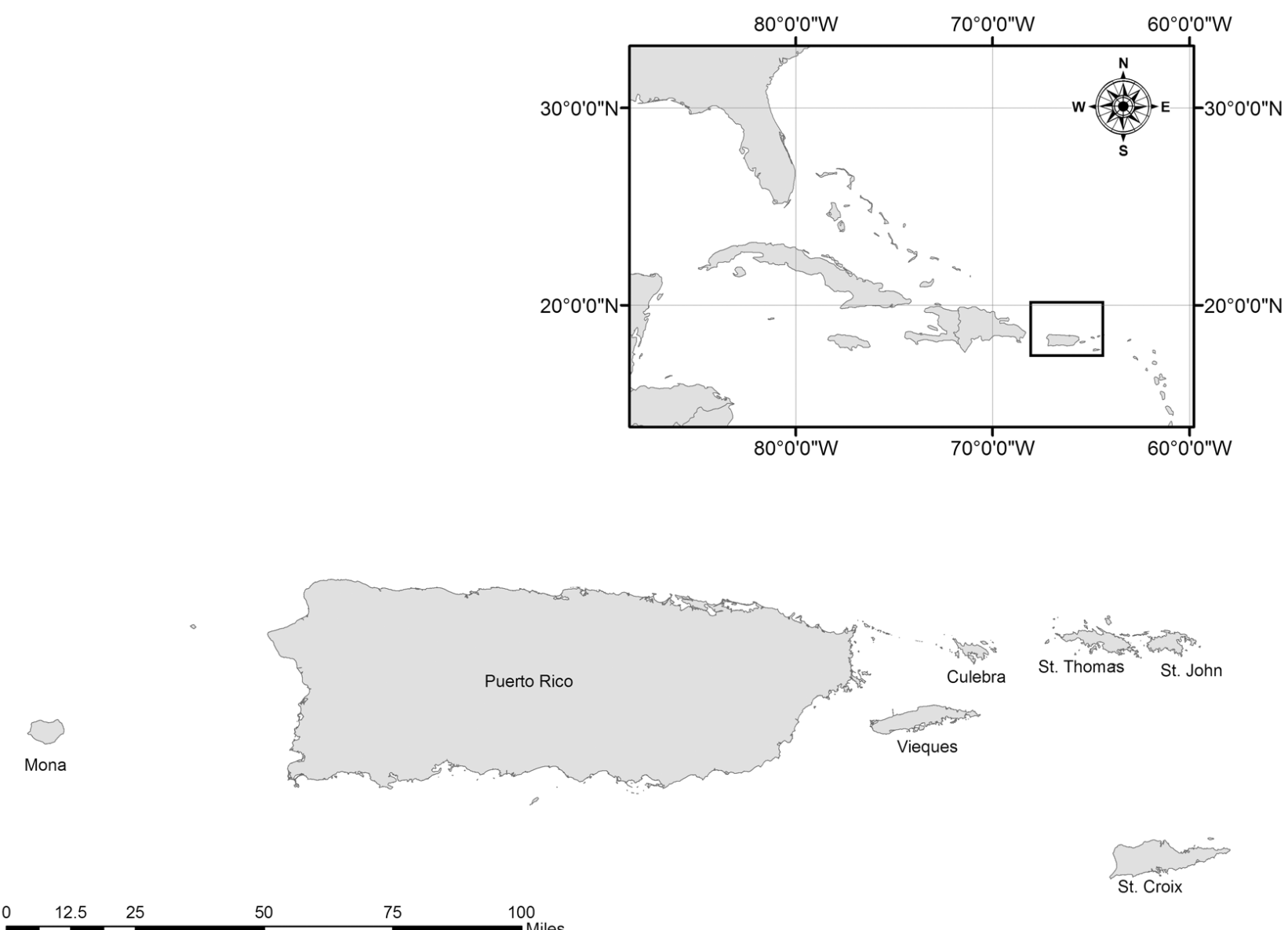

Figure 1.-The Commonwealth of Puerto Rico and environs.

Divers were interviewed using a standardized survey instrument that contained both closed and open-ended questions. The survey instrument collected information on demographics, capital investments (boats and fishing gear and equipment), fishing practices, and costs and earnings. In addition, it inquired about remunerative arrangements, crew organization and recruitment, and perceptions about the efficacy of the conch seasonal closure.

The survey was geographically stratified into four coastal areas: north, south, west, and east (Fig. 2). ${ }^{5}$ The stratification helped capture the diversity of operations and made the data collection easier and more economical to administer.

${ }^{5}$ The northern region extends from the municipalities of Isabela to Luquillo. The eastern region runs from the municipalities of Fajardo to Maunabo, including the islands of Vieques and Culebra, and the southern region stretches from the municipalities of Patillas to Lajas. The western region spans the municipalities of Cabo Rojo to Aguadilla.

Table 1.-Sampling statisitics.

\begin{tabular}{|c|c|c|c|c|c|}
\hline Regions & Diver population & $\begin{array}{l}\text { Target number } \\
\text { of interviews }\end{array}$ & $\begin{array}{c}\text { Number of } \\
\text { completed interviews }\end{array}$ & $\begin{array}{c}\text { Number of } \\
\text { nonresponses }\end{array}$ & $\begin{array}{l}\text { Number } \\
\text { of contacts }\end{array}$ \\
\hline East coast & 40 & 15 & 15 & 9 & 24 \\
\hline North coast & 18 & 7 & 7 & 4 & 11 \\
\hline South coast & 62 & 23 & 23 & 10 & 33 \\
\hline West coast & 99 & 36 & 36 & 35 & 71 \\
\hline
\end{tabular}

To satisfy the requirements of the sampling protocol, interviewers were instructed to select a replacement diver only if the one randomly selected either refused to participate in the survey; was unavailable due to illness, death, or travel; could not be contacted after six separate attempts; or was not identified by others at the fishing cooperative.

Despite the significant effort devoted to sampling, the unadjusted response rate was $58.3 \%$. The unadjusted response rate was obtained by dividing the total number of completed interviews by the total number of people contacted (Table 1). Reasons for nonresponse included that divers could not be reached (35), no longer qualified because they no longer dove (10), gear misclassification (9), and 


\section{Municipalities of Commonwealth Puerto Rico}

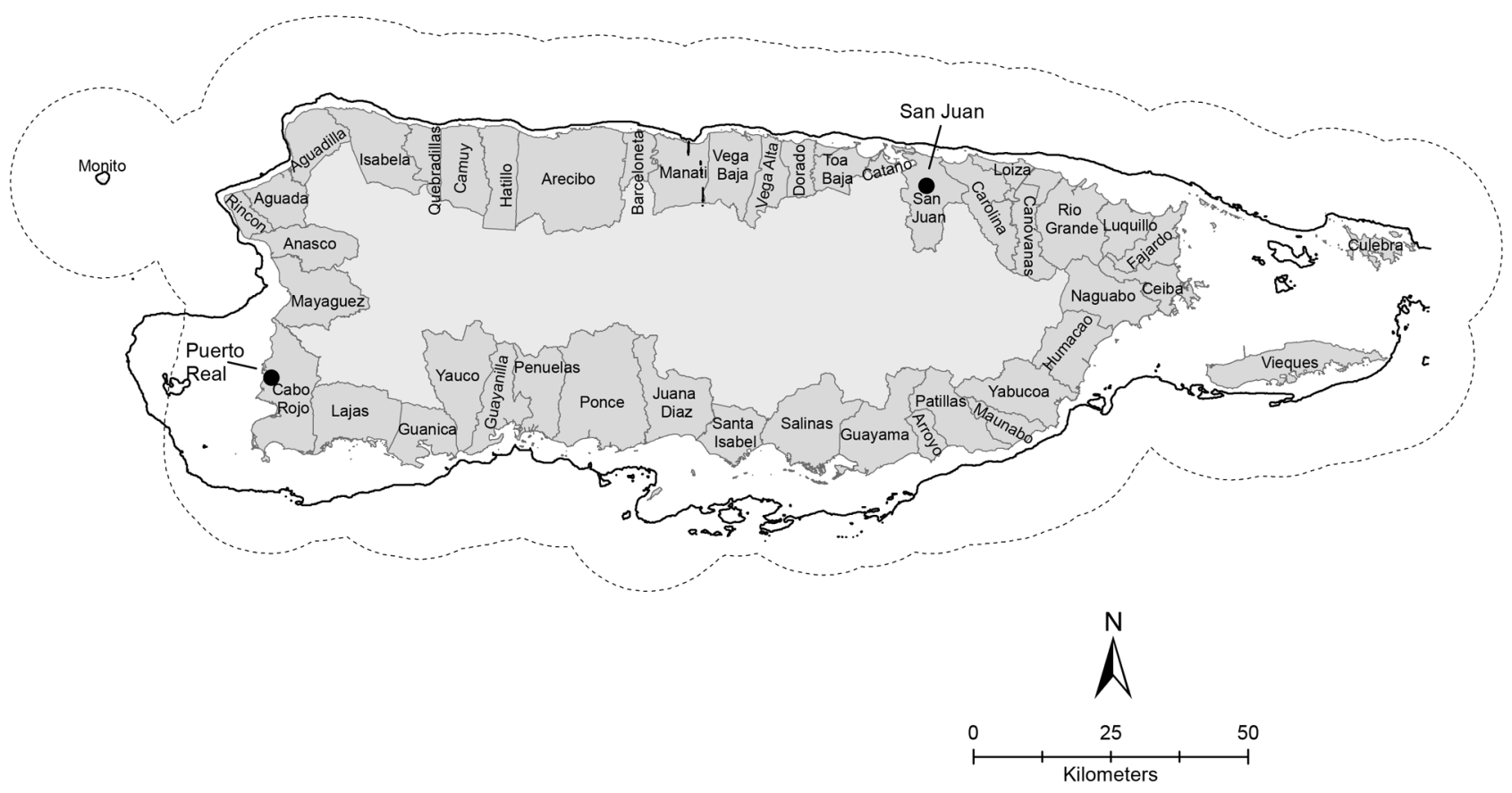

Figure 2.-Coastal municipalities in the Commonwealth of Puerto Rico.

refusals (4). The fieldwork took place between March 2014 and March 2015.

In addition, we conducted semistructured interviews with key informants to help us contextualize our findings. Key informants included established divers, fishery managers and port agents, and professionals involved in research and outreach. Unless otherwise noted, the tabulated summary statistics are frequencies or sample means with their standard error in parentheses.

\section{Results and Discussion}

\section{Demographic Profile}

Most of the divers surveyed were Hispanic middle-aged men with extensive fishing experience and high levels of fishing dependence (Table 2). Their ages ranged from 24 to 80 years, averaging 49 years. Almost $83 \%$ of the divers were in the 40 years and over age bracket, and less than $4 \%$ of the sample was in the under 30 years age bracket. However, during our fieldwork we noticed many young divers, mainly high school and college-aged students, who reportedly do not turn in landings statistics (hence, they were not in our sample frame) probably because they fish on a part-time (or seasonal) basis. Therefore, the small share of those under 30 captured in our sample may not be indicative of declining recruitment rates but rather of the rise of nontraditional recruitment processes, which previously relied on kinship relationships (Valdés-Pizzini, 1992).

Staff from Puerto Rico's Fisheries Research Laboratory and established fishermen related that nowadays young divers usually start free diving with spearguns close to shore on a parttime basis, but once they become more proficient they begin scuba diving in deeper waters on a full-time basis. Most respondents were owner-operators and stated that, on average, they have been fishing for nearly 27 years (range 3-71 years).

Fishing was found to be an integral part of the household economy. On average, fishing income contributed close to $80 \%$ of their household income. Most interviewees indicated that they fished year-round on a fulltime basis. Part-timers reported that they fished for income rather than for consumption purposes.

Divers spent, on average, $36 \mathrm{~h}$ per week on fishing and fishing related activities such as boat and engine maintenance and seafood marketing. Regional differences in participation and fishing dependence can be partially explained by geography (Table 2 ). For instance, the north coast has a narrow insular shelf and exposed coast that provides limited protection against rough seas which hampers fishing; however, the southwest coast has a shallow and extended shelf which makes fishing easier (Jarvis, 
1932; Suarez-Caabro, 1979; Matos and Agar, 2011). The number of dependents (including the diver) ranged between 1 and 7, with an average of 3.6 whereas the Commonwealth's average was 2.7 (Table 2).

In addition to fishing income, many fishermen receive government transfer (welfare) payments and may participate in markets for wage labor (Valdés-Pizzini, 1985; Griffith and Valdés-Pizzini, 2002; Pérez, 2005; Griffith et al., 2007). Much of this wage labor is derived from low paying, casual occupations (i.e., odd jobs or "chiripas" as they are known locally). Reportedly, full-time divers mainly engage in "chiripas" during the queen conch closure. ${ }^{6}$

Pérez (2005) notes that "chiripas" can play an important role in supplementing household incomes. Government transfer payments such as food stamps; health, utility, and housing subsidies; and social security are also important supplemental sources of household income. Over $70 \%$ of the divers surveyed declined to describe their involvement in nonfishing activities, probably because they feared that sharing this information could threaten their access to welfare programs.,

The remaining divers reported that they worked in miscellaneous jobs such as construction, fish sales, boat maintenance, plumbing, landscaping, and waiting tables, among others. Aside from diving, respondents also stated that they fished with handlines, traps, vertical lines, and miscellaneous

${ }^{6}$ Daniel Matos-Caraballo from Puerto Rico's Fisheries Research Laboratory. Personal commun., March, 2016.

${ }^{7}$ Krueger et al. (2015) report that a 3-member household that receives food stamps, Aid to Families with Dependent Children (AFDC), Medicaid, and utilities subsidies can collect $\$ 1,743$ per month, which is significantly higher than the $\$ 1,159$ that a minimum wage earner could earn. Moreover, the Bureau of Labor Statistics (2017a) reports that the 2014 median hourly wage rate for an individual employed in farming, fishing, and forestry occupations in Puerto Rico was \$8.96, which translates to a median monthly wage of $\$ 1,434$ which is lower than the above-mentioned welfare payments.

${ }^{8}$ Agar et al. (2005) report that Puerto Rican fish trap fishermen were also unwilling to share information on their nonfishing activities.
Table 2.-Demographic profile by coastal area.

\begin{tabular}{|c|c|c|c|c|c|c|}
\hline Variable & $\begin{array}{l}\text { East } \\
\text { coast }\end{array}$ & $\begin{array}{l}\text { North } \\
\text { coast }\end{array}$ & $\begin{array}{l}\text { South } \\
\text { coast }\end{array}$ & $\begin{array}{l}\text { West } \\
\text { coast }\end{array}$ & $\begin{array}{l}\text { Island- } \\
\text { wide }\end{array}$ & $\begin{array}{l}\text { Number of } \\
\text { respondents }\end{array}$ \\
\hline Fishing role (\%) & & & & & & 81 \\
\hline Captain-owner & 93.3 & 85.7 & 73.9 & 80.6 & 81.5 & \\
\hline Hired captain & & & 13.0 & 8.3 & 7.4 & \\
\hline Crew & 6.7 & 14.3 & 13.0 & 11.1 & 11.1 & \\
\hline Age (years) & $\begin{array}{c}50.3 \\
(1.9)\end{array}$ & $\begin{array}{c}48.7 \\
(4.0)\end{array}$ & $\begin{array}{l}46.1 \\
(2.0)\end{array}$ & $\begin{array}{c}50.6 \\
(1.5)\end{array}$ & $\begin{array}{l}49.0 \\
(1.0)\end{array}$ & 81 \\
\hline Age distribution (\%) & & & & & & 81 \\
\hline$<30$ years & & & 4.4 & 5.6 & 3.7 & \\
\hline $30-39$ & & 28.6 & 26.1 & 8.3 & 13.6 & \\
\hline $40-49$ & 60.0 & 28.6 & 39.1 & 33.3 & 39.5 & \\
\hline $50-59$ & 20.0 & 14.3 & 13.0 & 36.1 & 24.7 & \\
\hline $60-69$ & 20.0 & 28.6 & 17.4 & 11.1 & 16.1 & \\
\hline$>=70$ & & & & 5.6 & 2.5 & \\
\hline Fishing experience (years) & $\begin{array}{c}29.9 \\
(3.2)\end{array}$ & $\begin{array}{c}15.1 \\
(6.3)\end{array}$ & $\begin{array}{l}22.7 \\
(2.4)\end{array}$ & $\begin{array}{c}29.9 \\
(1.8)\end{array}$ & $\begin{array}{c}26.5 \\
(1.3)\end{array}$ & 81 \\
\hline Fish year-round (\%) & 100 & 100 & 91.3 & 97.2 & 96.3 & 81 \\
\hline Full-time (\%) & 86.7 & 71.4 & 91.3 & 85.7 & 86.3 & 80 \\
\hline $\begin{array}{l}\text { Time spent on fishing } \\
\text { activities (h/wk) }\end{array}$ & $\begin{array}{c}44.4 \\
(4.3)\end{array}$ & $\begin{array}{c}39.9 \\
(6.5)\end{array}$ & $\begin{array}{c}36.6 \\
(2.0)\end{array}$ & $\begin{array}{c}31.7 \\
(1.0)\end{array}$ & $\begin{array}{c}36.2 \\
(1.2)\end{array}$ & 78 \\
\hline $\begin{array}{l}\text { Household income derived } \\
\text { from fishing (\%) }\end{array}$ & $\begin{array}{c}78.7 \\
(7.2)\end{array}$ & $\begin{array}{c}67.6 \\
(14.6)\end{array}$ & $\begin{array}{c}78.3 \\
(5.0)\end{array}$ & $\begin{array}{l}82.4 \\
(3.6)\end{array}$ & $\begin{array}{l}79.4 \\
(2.8)\end{array}$ & 79 \\
\hline Number of dependents & $\begin{array}{l}3.0 \\
(0.2)\end{array}$ & $\begin{array}{l}3.7 \\
(0.6)\end{array}$ & $\begin{array}{l}4.0 \\
(0.3)\end{array}$ & $\begin{array}{l}3.6 \\
(0.2)\end{array}$ & $\begin{array}{l}3.6 \\
(0.1)\end{array}$ & 81 \\
\hline
\end{tabular}

nets, and that spiny lobster, queen conch, and various reef-fish were their mainstay species (Table 3). About 75\% of the divers said that they primarily fished in Commonwealth waters $(<9$ nmi).

\section{Capital Investment in \\ Boats, Fishing Gear, and Electronic Equipment}

Most boats were relatively small and had limited technology (Table 4). The average boat was about $20 \mathrm{ft}(13-27 \mathrm{ft}$ range) powered with a single outboard gasoline engine, averaging $76 \mathrm{hp} \mathrm{(8-}$ $300 \mathrm{hp}$ range). ${ }^{9}$ Most hulls were made of fiberglass and, to a lesser extent, of a combination of fiberglass and wood, or simply wood. ${ }^{10}$ On average, divers valued their used boat and engine at $\$ 7,556$ and stated that annual mainte-

${ }^{9}$ Valdés-Pizzini (1985) reports that in the 1980's the Puerto Real-based dive fleet was made up of 15-21 ft boats powered with 40-125 hp outboard engines.

${ }^{10} \mathrm{~A}$ port agent observed that rudimentary boats found on the west coast (mainly wooden or fiberglass-wood hulls) are called "Dominicanos" because they were left behind by undocumented Dominican immigrants after crossing the Mona Passage. nance costs were about $\$ 1,750$ (Table 4).

In addition to the boat and engine, diving, electronic, and safety equipment are important components of the capital stock held by divers (Table 4 ). Divers valued their diving equipment (i.e., tanks, regulators, spearguns, etc.) at about \$1,148 and spent \$293 annually on its maintenance. They also estimated that their electronic (e.g., cellular phones, global positioning systems, radio, and fish and depth finders) and safety equipment (e.g., personal flotation devices, fire extinguisher, etc.) were worth about $\$ 703$ and \$246, respectively.

\section{Fishing Practices}

Diving operations reported mainly targeting queen conch, spiny lobster, and/or various reef-fish. Most diving operations fish every day for 6-7 $\mathrm{h}$ and have a small crew of 2-3 (Table 5). Fishing excursions usually start early in the morning (around 5-6 a.m.) and end at noon or early in the afternoon (12-2 p.m.) before the wind picks up. Aggregate landings ranged from 15 to (Table 6). $225 \mathrm{lb}$ per trip, averaging about $56 \mathrm{lb}$ 
Table 3.-Main fishing gears and target species by coastal region.

\begin{tabular}{|c|c|c|c|c|c|c|}
\hline Variable & $\begin{array}{l}\text { East } \\
\text { coast }\end{array}$ & $\begin{array}{l}\text { North } \\
\text { coast }\end{array}$ & $\begin{array}{l}\text { South } \\
\text { coast }\end{array}$ & $\begin{array}{l}\text { West } \\
\text { coast }\end{array}$ & $\begin{array}{l}\text { Island- } \\
\text { wide }\end{array}$ & $\begin{array}{l}\text { Number of } \\
\text { respondents }\end{array}$ \\
\hline \multicolumn{6}{|l|}{ Percentage of fishermen who use } & 81 \\
\hline Vertical line & & 14.3 & 21.7 & 13.9 & 13.6 & \\
\hline Longline & & & & 2.8 & 1.2 & \\
\hline Handline & 26.7 & 42.9 & 52.2 & 33.3 & 38.3 & \\
\hline Shark longline & & & 4.4 & & 1.2 & \\
\hline Rod and reel & & & 26.1 & 2.8 & 8.6 & \\
\hline Troll & & 14.3 & 21.7 & 5.6 & 9.9 & \\
\hline Fish and lobster trap & 26.7 & 14.3 & 17.4 & 8.3 & 14.8 & \\
\hline Trammel net & 13.3 & & 8.7 & 5.6 & 7.4 & \\
\hline Cast net & & & 17.4 & 8.3 & 8.6 & \\
\hline Beach seine & & & 13.0 & 8.3 & 7.4 & \\
\hline Gillnet & 6.7 & & & 2.8 & 2.5 & \\
\hline \multirow{2}{*}{\multicolumn{7}{|c|}{$\begin{array}{l}\text { Percentage of fishermen who } \\
\text { target the following species (\%) }\end{array}$}} \\
\hline & & & & & & 81 \\
\hline Deep-water snapper-grouper & 13.3 & 71.4 & 82.6 & 77.8 & 66.7 & \\
\hline Reef-fish & 100 & 57.1 & 91.3 & 58.3 & 75.3 & \\
\hline Dolphin/Wahoo & & 14.3 & 30.4 & 13.9 & 16.1 & \\
\hline Tuna & & 14.3 & 8.7 & 8.3 & 7.4 & \\
\hline Shark & & 14.3 & 17.4 & 8.3 & 9.9 & \\
\hline Lobster & 100 & 85.7 & 100 & 100 & 98.8 & \\
\hline Conch & 100 & 42.9 & 100 & 100 & 95.1 & \\
\hline Baitfish & & & 17.4 & 13.9 & 11.1 & \\
\hline \multicolumn{7}{|l|}{ Ornamental fish } \\
\hline Miscellaneous species & 26.7 & 28.6 & 91.3 & 52.8 & 56.8 & \\
\hline \multicolumn{7}{|l|}{$\begin{array}{l}\text { Percentage of fishermen who fish } \\
\text { in the following waters (\%) }\end{array}$} \\
\hline Territorial waters & 100 & 100 & 78.3 & 58.3 & 75.3 & 01 \\
\hline \multicolumn{7}{|l|}{ Federal waters } \\
\hline Both & & & 21.7 & 41.7 & 24.7 & \\
\hline
\end{tabular}

Diving teams are composed of a helmsman (or boat tender) and one or more divers (Valdés-Pizzini, 1985; Appeldorn, 1997). The helmsman is responsible for navigating, hauling the catch, and tending the boat to ensure the safety of the divers who are fishing underwater (Valdés-Pizzini, 1992). About $90 \%$ of the owner-operators in our sample were divers. Divers reported using 2-3 air tanks each per trip, although some used as many as 6 tanks. Diving depths ranged from 10 to 150 $\mathrm{ft}$.

Diving is a dangerous and potentially life-threatening activity. Respondents were aware of the causes and dangers of decompression sickness (or "burbuja" as it is locally known) but offered a number of explanations for (wittingly or unwittingly) disregarding safety guidelines. The two most commonly cited reasons were economic pressures followed by operational carelessness. They explained that they were more liable to take additional dives and/or prolong dives if poor weather conditions had prevented them from fishing in recent days or if the first few tanks were unproductive.
They also mentioned that divers are tempted to dive longer if they find productive aggregations in the latter part of the trip. Some divers reported using a fourth tank to catch conch in 70-90 $\mathrm{ft}$ depths.

Divers also cited fatigue, overexertion (due to strong currents), overconfidence (especially by younger divers), equipment failure, and improperly accounting for residual nitrogen during multi-day and multi-tank dives for the increased risk of decompression sickness. Surprisingly, many divers reported going diving the next day after experiencing a "mild" bends event (or "chispitos" as locally known); however, they added that in these cases, they generally dove in shallower waters and for a shorter period of time for a few days.

A key informant mentioned additional factors that place the health of divers in danger. ${ }^{11}$ He noted that many divers do not have diving licenses which forces them to refill their tanks in places with poor air quality because

\footnotetext{
${ }^{11}$ Ruperto Chaparro Serrano, Director of the Puerto Rico's SeaGrant Program. Personal commun., April, 2016.
}

compressors may not work properly or are housed in places with poor ventilation. Additionally, some divers are habitual consumers of alcohol and drugs which impair their judgment and physical performance. It was also noted that many divers do not have medical insurance for work related accidents. The first treatment in a hyperbaric chamber (with helicopter transportation) can cost up to $\$ 10,000$. Moreover, injured divers seeking treatment waste valuable time by initially going to local emergency rooms, which have limited experience with diving-related accidents, rather than going directly to medical centers with hyperbaric chambers.

Divers use a variety of fishing equipment to target a diverse and variable resource base. Besides using their hands to harvest conch and lobster, divers may also employ snares to catch lobster and gaffs to catch octopus (and occasionally to illegally catch lobster). Spearguns are also used mainly to catch various reef-fishes such as, snappers (Lutjanidae), hogfishes (Labridae), and triggerfishes (Balistidae), but sometimes they are unlawfully used to harvest lobsters.

Depending on the species pursued, divers may operate over a wide range of habitat types. For example, divers targeting queen conch gather them on seagrass beds and sandy bottoms, whereas those targeting spiny lobsters and reef-fishes catch them on hard bottoms and reef areas. Once a suitable queen conch aggregation is located, divers usually shuck the conch underwater and load the meat into baskets or mesh bags, which are lifted using a winch (or manually) and emptied onboard.

Conchs are usually shucked with a hatchet or hammer and chisel (Appeldorn, 1991). ${ }^{12}$ Divers dislike shucking onboard (or on land) because of the added physical exertion of gathering and raising live conchs onboard and the added load of the shells which

\footnotetext{
${ }^{12}$ According to one of the most seasoned divers in the south coast, Dominican inmigrants were the first ones to shuck conchs underwater in Puerto Rico.
} 
Table 4.-Vessel characteristics by coastal region.

\begin{tabular}{|c|c|c|c|c|c|c|}
\hline Variable & $\begin{array}{l}\text { East } \\
\text { coast }\end{array}$ & $\begin{array}{l}\text { North } \\
\text { coast }\end{array}$ & $\begin{array}{l}\text { South } \\
\text { coast }\end{array}$ & $\begin{array}{l}\text { West } \\
\text { coast }\end{array}$ & $\begin{array}{l}\text { Island- } \\
\text { wide }\end{array}$ & $\begin{array}{l}\text { Number of } \\
\text { respondents }\end{array}$ \\
\hline Boat length (ft) & $\begin{array}{c}19.9 \\
(0.5)\end{array}$ & $\begin{array}{c}20.3 \\
(0.7)\end{array}$ & $\begin{array}{c}19.1 \\
(0.5)\end{array}$ & $\begin{array}{c}19.6 \\
(0.3)\end{array}$ & $\begin{array}{c}19.6 \\
(0.2)\end{array}$ & 81 \\
\hline Engine propulsion (hp) & $\begin{array}{c}68.9 \\
(6.1)\end{array}$ & $\begin{array}{c}85.7 \\
(14.6)\end{array}$ & $\begin{array}{c}93.8 \\
(13.0)\end{array}$ & $\begin{array}{c}64.6 \\
(4.7)\end{array}$ & $\begin{array}{c}75.9 \\
(4.7)\end{array}$ & 81 \\
\hline Hull type (\%) & & & & & & 79 \\
\hline Fiberglass & 100 & 71.4 & 77.3 & 85.7 & 84.8 & \\
\hline Wood & & 14.3 & 4.6 & 8.6 & 6.3 & \\
\hline Fiberglass and wood & & 14.3 & 18.2 & 5.7 & 8.9 & \\
\hline Percentage of engines & & & & & & 81 \\
\hline Single & 86.7 & 85.7 & 95.7 & 91.7 & 91.4 & \\
\hline Twin & 13.3 & 14.3 & 4.4 & 8.3 & 8.6 & \\
\hline Engine type (\%) & & & & & & 81 \\
\hline Inboard & & & & 5.6 & 2.5 & \\
\hline Outboard & 100 & 100 & 100 & 94.4 & 97.5 & \\
\hline Fuel type (\%) & & & & & & 81 \\
\hline Gasoline & 100 & 100 & 100 & 94.4 & 97.5 & \\
\hline Diesel & & & & 5.6 & 2.5 & \\
\hline Value of used boat and engines (\$) & $\begin{array}{c}8,346.2 \\
(1,299.3)\end{array}$ & $\begin{array}{c}7,700.0 \\
(2,568.9)\end{array}$ & $\begin{array}{c}8,175.1 \\
(1,556.5)\end{array}$ & $\begin{array}{c}6,822.7 \\
(931.7)\end{array}$ & $\begin{array}{c}7,556.2 \\
(694.5)\end{array}$ & 73 \\
\hline Annual maintenance costs (incl. engines, \$) & $\begin{array}{c}1,656.7 \\
(498.0)\end{array}$ & $\begin{array}{c}1,157.1 \\
(370.7)\end{array}$ & $\begin{array}{r}2,173.7 \\
(516.3)\end{array}$ & $\begin{array}{c}1,636.7 \\
(305.9)\end{array}$ & $\begin{array}{c}1,750.2 \\
(222.8)\end{array}$ & 71 \\
\hline \multicolumn{7}{|l|}{ Diving equipment (\%) } \\
\hline Spearguns & 93.3 & 85.7 & 87.0 & 82.9 & 86.2 & 80 \\
\hline Gaffs & 13.3 & 0 & 60.9 & 14.3 & 26.2 & 80 \\
\hline Snares & 93.3 & 57.1 & 56.5 & 77.1 & 72.5 & 80 \\
\hline \multicolumn{7}{|l|}{ Electronic equipment (\%) } \\
\hline GPS & 53.3 & 57.1 & 26.1 & 68.6 & 52.5 & 80 \\
\hline Winch & & 28.6 & 4.4 & 5.7 & 6.3 & 80 \\
\hline Depth finder & 13.3 & 42.9 & 13.0 & 20.0 & 18.8 & 80 \\
\hline Fish finder & 13.3 & 57.1 & 13.0 & 5.7 & 13.8 & 80 \\
\hline Radio & 13.3 & 71.4 & 13.0 & 14.3 & 18.8 & 80 \\
\hline Cellular & 100 & 100 & 81.8 & 79.4 & 85.9 & 78 \\
\hline EPIRB & & 14.3 & & 5.7 & 3.8 & 80 \\
\hline Value of diving equipment (\$) & $\begin{array}{r}1,170.0 \\
(198.6)\end{array}$ & $\begin{array}{r}1,464.3 \\
(637.3)\end{array}$ & $\begin{array}{r}1,097.3 \\
(137.4)\end{array}$ & $\begin{array}{r}1,110.6 \\
(129.1)\end{array}$ & $\begin{array}{r}1,148.2 \\
(95.4)\end{array}$ & 76 \\
\hline Value of safety equipment (\$) & $\begin{array}{c}235.7 \\
(29.1)\end{array}$ & $\begin{array}{l}225.7 \\
(58.5)\end{array}$ & $\begin{array}{c}219.2 \\
(23.1)\end{array}$ & $\begin{array}{c}273.6 \\
(25.2)\end{array}$ & $\begin{array}{c}246.3 \\
(14.8)\end{array}$ & 76 \\
\hline Value of electronic equipment (\$) & $\begin{array}{c}426.7 \\
(113.9)\end{array}$ & $\begin{array}{c}1,917.1 \\
(704.9)\end{array}$ & $\begin{array}{c}486.9 \\
(132.2)\end{array}$ & $\begin{array}{c}752.0 \\
(141.0)\end{array}$ & $\begin{array}{c}702.5 \\
(95.9)\end{array}$ & 76 \\
\hline Maintenance costs of diving equipment ( $\$ / y r)$ & $\begin{array}{c}189.0 \\
(39.2)\end{array}$ & $\begin{array}{c}332.9 \\
(107.7)\end{array}$ & $\begin{array}{c}291.9 \\
(57.1)\end{array}$ & $\begin{array}{c}335.2 \\
(54.7)\end{array}$ & $\begin{array}{c}293.4 \\
(31.0)\end{array}$ & 75 \\
\hline
\end{tabular}

can make the small craft unstable. Commonwealth regulations set a daily quota of 150 conchs per licensed fisherman up to a maximum of 450 conchs per vessel (with three licensed fishermen onboard).

\section{Revenues and Costs}

Divers reported various economic objectives for their fishing trips. Broadly speaking, about two-thirds $(67 \%)$ of the interviewees said that they wanted to reach a certain catch and/or income target (e.g., landing 80 pounds of octopus, making a small recellaneous objectives such as enjoyment or to try one's luck. Somewhat surprising, about $31 \%$ of the catch or income targeters said that they simply wanted to cover trip costs, which is consistent with finding of other socioeconomic studies of small-scale fisheries (Salas and Gaetner, 2004). Though recouping trip costs is crucial to cope with irregular fishing income, we be- lieve that most cost defrayers longed for sufficient income not only to finance their next trip (i.e., cover costs) but also to satisfy basic household needs.

Diving operations gross returns per trip ranged from $\$ 75$ to $\$ 700$, averaging \$251 (Table 6). ${ }^{13}$ Fuel and oil expenses accounted for $61 \%$ of the nonlabor variable costs. ${ }^{14}$ Diving boats used between 4 and 28 gallons of fuel per trip, averaging 11 gallons. Air refills and grocery expenses were responsible for $25 \%$ and $10 \%$ of the nonlabor variable costs, respectively. Ice costs were minor because less than $23 \%$ of the interviewees iced their catch. After deducting nonlabor variable costs (e.g., fuel, air refills, groceries, etc.), net returns per trip ranged from $\$ 15$ to $\$ 600$, averaging $\$ 169$ (Table 6).

\section{Remunerative Arrangements}

The lay arrangement was the dominant income sharing mechanism. Under lay arrangements, capital and labor are remunerated based on a percentage of the net returns (gross revenues minus variable expenses) rather than a fixed wage. Lay arrangements are designed to cope with fluctuating catches and prices. They help spread production risk because the boat owner's labor obligations are reduced if catches are poor. Conversely, boat owners' returns are dampened when catches are bountiful making it harder to amass capital and discharge debts (Symes and Frangoudes, 2001). In addition to spreading risk, lay arrangements encourage and reward teamwork and productivity by making each crew member a partner in the enterprise (Acheson, 1981; Doeringer et al., 1986).

The survey showed that income sharing rules between capital and labor

\footnotetext{
${ }^{13}$ Divers also sell natural queen conch pearls but their occurrence is very rare. Pearls retail between $\$ 300$ and $\$ 30,000$ depending on their size and quality.

${ }^{14}$ When we asked if they would change the way they operated if gasoline prices rose significantly about $40 \%$ said they would. The most frequently cited coping mechanisms were to fish closer to shore and raise fish prices. Only one of the divers proposed reducing the size of the crew or switching fishing gears.
} 
varied significantly and that these were not always clear cut, particularly when the boat owner was one of the divers (Boncoeur et al., 2000; Guillen et al., $2015)$. Just over half $(51 \%)$ of the interviewees reported that boat owners did not receive a boat share; however, they acknowledged that crew members contributed when repairs were needed. ${ }^{15}$ The two main reasons offered for ceding the boat share were crew coownership of the enterprise (kin-based enterprise) and meager returns. Another $21 \%$ of the interviewees stated that there was not an explicit boat share, but explained that, for owners of larger boats, the owner share implicitly accounted for an unspecified return on capital and/or an allowance for maintenance expenses. An additional 20\% said that boat owners charged a fixed amount for upkeep that ranged from $\$ 5$ to $\$ 55$ per trip. Only $7 \%$ of the respondents reported that there was an overt boat share that ranged from $15 \%$ to $35 \%$.

The distribution of income between owner-operators and crew was fairly egalitarian. By and large, owner-operator and crew shares were roughly inversely related to the size of the labor force. For example, in 2-person operations, the average owner operator share was about 55\% (range 33$75 \%$ ). About $67 \%$ of these operations reported an equal allocation of fishing income between owner-operators and crew. Similarly, in 3-person operations, the average owner-operator share was about 34\% (range 25-50\%).

About $71 \%$ of these operations reported that fishing income was equally split between owner-operators and crew. Interviewees argued that the egalitarian distribution of income helped motivate and fairly reward crew since diving is a dangerous and labor intensive activity. Divers said that they placed their lives at risk every time they went out fishing. In addition, they
Table 5.-Fishing practices by coastal region.

Table 6. - Costs and earnings of diving operations by coastal region.

\begin{tabular}{|c|c|c|c|c|c|c|}
\hline Variable & $\begin{array}{l}\text { East } \\
\text { coast }\end{array}$ & $\begin{array}{l}\text { North } \\
\text { coast }\end{array}$ & $\begin{array}{l}\text { South } \\
\text { coast }\end{array}$ & $\begin{array}{l}\text { West } \\
\text { coast }\end{array}$ & $\begin{array}{l}\text { Island- } \\
\text { wide }\end{array}$ & $\begin{array}{l}\text { Number of } \\
\text { respondents }\end{array}$ \\
\hline Average landings (Ib/trip) & $\begin{array}{l}94.9 \\
13.3)\end{array}$ & $\begin{array}{c}53.3 \\
(6.9)\end{array}$ & $\begin{array}{c}45.3 \\
(3.6)\end{array}$ & $\begin{array}{c}46.4 \\
(2.9)\end{array}$ & $\begin{array}{c}55.5 \\
(3.0)\end{array}$ & 78 \\
\hline \multicolumn{7}{|l|}{ Variable Costs (\$/trip) } \\
\hline Fuel expenditures & $\begin{array}{l}68.7 \\
(7.5)\end{array}$ & $\begin{array}{c}65.7 \\
(14.8)\end{array}$ & $\begin{array}{c}42.5 \\
(3.3)\end{array}$ & $\begin{array}{l}41.1 \\
(2.8)\end{array}$ & $\begin{array}{c}48.4 \\
(2.4)\end{array}$ & 81 \\
\hline Trailer fuel expenses & $\begin{array}{c}0.9 \\
(0.6)\end{array}$ & $\begin{array}{c}16.1 \\
(6.4)\end{array}$ & $\begin{array}{c}0 \\
(0)\end{array}$ & $\begin{array}{c}0.2 \\
(0.1)\end{array}$ & $\begin{array}{c}1.5 \\
(0.5)\end{array}$ & 81 \\
\hline Ice expenditures & $\begin{array}{c}2.3 \\
(1.3)\end{array}$ & $\begin{array}{l}4.7 \\
(2.9)\end{array}$ & $\begin{array}{c}0.3 \\
(0.2)\end{array}$ & $\begin{array}{c}0.6 \\
(0.2)\end{array}$ & $\begin{array}{l}1.1 \\
(0.3)\end{array}$ & 81 \\
\hline Bait expenditures & $\begin{array}{c}0 \\
(0)\end{array}$ & $\begin{array}{l}2.1 \\
(2.0)\end{array}$ & $\begin{array}{c}0.9 \\
(0.7)\end{array}$ & $\begin{array}{c}0.5 \\
(0.4)\end{array}$ & $\begin{array}{c}0.7 \\
(0.3)\end{array}$ & 81 \\
\hline Air refill expenditures & $\begin{array}{c}26.1 \\
(3.5)\end{array}$ & $\begin{array}{c}12.3 \\
(3.3)\end{array}$ & $\begin{array}{c}19.9 \\
(1.9)\end{array}$ & $\begin{array}{l}20.1 \\
(1.3)\end{array}$ & $\begin{array}{c}20.5 \\
(1.1)\end{array}$ & 81 \\
\hline Food expenditures & $\begin{array}{l}12.8 \\
(1.5)\end{array}$ & $\begin{array}{l}11.7 \\
(3.9)\end{array}$ & $\begin{array}{c}7.9 \\
(1.1)\end{array}$ & $\begin{array}{l}5.6 \\
(0.7)\end{array}$ & $\begin{array}{l}8.1 \\
(0.6)\end{array}$ & 81 \\
\hline Other expenditures & $\begin{array}{c}0.3 \\
(0.3)\end{array}$ & $\begin{array}{c}4.3 \\
(3.4)\end{array}$ & $\begin{array}{c}1.2 \\
(0.9)\end{array}$ & $\begin{array}{c}0.0 \\
(0.0)\end{array}$ & $\begin{array}{c}0.8 \\
(0.4)\end{array}$ & 81 \\
\hline Gross earnings (\$/trip) & $\begin{array}{c}410.7 \\
(36.4)\end{array}$ & $\begin{array}{c}225.7 \\
(13.3)\end{array}$ & $\begin{array}{c}192.0 \\
(13.7)\end{array}$ & $\begin{array}{c}230.2 \\
(14.8)\end{array}$ & $\begin{array}{c}251.1 \\
(10.1)\end{array}$ & 78 \\
\hline Total variable costs (\$/trip) & $\begin{array}{r}111.8 \\
(9.4)\end{array}$ & $\begin{array}{c}113.6 \\
(20.0)\end{array}$ & $\begin{array}{c}73.0 \\
(4.4)\end{array}$ & $\begin{array}{c}68.9 \\
(3.4)\end{array}$ & $\begin{array}{c}81.4 \\
(3.1)\end{array}$ & 81 \\
\hline Net earnings (\$/trip) & $\begin{array}{c}299.0 \\
(33.5)\end{array}$ & $\begin{array}{r}112.1 \\
(8.7)\end{array}$ & $\begin{array}{c}119.6 \\
(12.9)\end{array}$ & $\begin{array}{c}160.8 \\
(14.4)\end{array}$ & $\begin{array}{r}169.3 \\
(9.6)\end{array}$ & 78 \\
\hline Fuel consumption (gallons) & $\begin{array}{c}16.3 \\
(1.8)\end{array}$ & $\begin{array}{c}12.0 \\
(2.6)\end{array}$ & $\begin{array}{c}9.5 \\
(0.8)\end{array}$ & $\begin{array}{c}9.3 \\
(0.5)\end{array}$ & $\begin{array}{c}10.9 \\
(0.5)\end{array}$ & 71 \\
\hline Ice use (\%) & 40.0 & 71.4 & 13.0 & 16.7 & 23.5 & 81 \\
\hline
\end{tabular}

\begin{tabular}{|c|c|c|c|c|c|c|}
\hline Variable & $\begin{array}{c}\text { East } \\
\text { coast }\end{array}$ & $\begin{array}{l}\text { North } \\
\text { coast }\end{array}$ & $\begin{array}{l}\text { South } \\
\text { coast }\end{array}$ & $\begin{array}{l}\text { West } \\
\text { coast }\end{array}$ & $\begin{array}{l}\text { Island- } \\
\text { wide }\end{array}$ & $\begin{array}{l}\text { Number of } \\
\text { respondents }\end{array}$ \\
\hline Number of trips (trips/wk) & $\begin{array}{l}4.6 \\
(0.3)\end{array}$ & $\begin{array}{l}3.7 \\
(0.5)\end{array}$ & $\begin{array}{c}4.3 \\
(0.3)\end{array}$ & $\begin{array}{c}4.7 \\
(0.2)\end{array}$ & $\begin{array}{c}4.5 \\
(0.1)\end{array}$ & 81 \\
\hline Trip duration (h/trip) & $\begin{array}{l}6.6 \\
(0.3)\end{array}$ & $\begin{array}{c}7.4 \\
(1.0)\end{array}$ & $\begin{array}{c}6.3 \\
(0.2)\end{array}$ & $\begin{array}{c}6.4 \\
(0.2)\end{array}$ & $\begin{array}{c}6.5 \\
(0.2)\end{array}$ & 80 \\
\hline Total crew (incl. captain) & $\begin{array}{l}2.7 \\
(0.2)\end{array}$ & $\begin{array}{l}2.0 \\
(0)\end{array}$ & $\begin{array}{c}2.4 \\
(0.1)\end{array}$ & $\begin{array}{c}2.3 \\
(0.1)\end{array}$ & $\begin{array}{l}2.4 \\
(0)\end{array}$ & 81 \\
\hline $\begin{array}{l}\text { Crew distribution (\%) } \\
1 \text { member } \\
2 \text { members } \\
3 \text { members } \\
4 \text { members }\end{array}$ & $\begin{array}{l}40.0 \\
46.7 \\
13.3\end{array}$ & 100.0 & $\begin{array}{l}60.9 \\
39.1\end{array}$ & $\begin{array}{r}2.8 \\
72.2 \\
22.2 \\
2.8\end{array}$ & $\begin{array}{r}1.2 \\
65.4 \\
29.6 \\
3.7\end{array}$ & 81 \\
\hline Number of scuba divers & $\begin{array}{c}1.9 \\
(0.2)\end{array}$ & $\begin{array}{c}1.7 \\
(0.2)\end{array}$ & $\begin{array}{c}1.5 \\
(0.1)\end{array}$ & $\begin{array}{c}1.5 \\
(0.1)\end{array}$ & $\begin{array}{c}1.6 \\
(0.1)\end{array}$ & 71 \\
\hline $\begin{array}{l}\text { Frequency scuba divers (\%) } \\
\text { One } \\
\text { Two } \\
\text { Three }\end{array}$ & $\begin{array}{l}28.6 \\
57.1 \\
14.3\end{array}$ & $\begin{array}{l}33.3 \\
66.7\end{array}$ & $\begin{array}{l}50.0 \\
50.0\end{array}$ & $\begin{array}{l}54.8 \\
45.2\end{array}$ & $\begin{array}{r}46.5 \\
50.7 \\
2.8\end{array}$ & 71 \\
\hline Number of tanks per diver & $\begin{array}{c}3.9 \\
(0.2)\end{array}$ & $\begin{array}{l}3.0 \\
(0.4)\end{array}$ & $\begin{array}{l}3.6 \\
(0.3)\end{array}$ & $\begin{array}{l}3.5 \\
(0.2)\end{array}$ & $\begin{array}{l}3.6 \\
(0.1)\end{array}$ & 71 \\
\hline $\begin{array}{l}\text { Frequency tanks per diver (\%) } \\
\text { One } \\
\text { Two } \\
\text { Three } \\
\text { Four } \\
\text { Five or more }\end{array}$ & $\begin{array}{l}28.6 \\
57.1 \\
14.3\end{array}$ & $\begin{array}{l}50.0 \\
50.0\end{array}$ & $\begin{array}{r}10.0 \\
15.0 \\
5.0 \\
45.0 \\
25.0\end{array}$ & $\begin{array}{r}6.5 \\
12.9 \\
19.4 \\
54.8 \\
6.5\end{array}$ & $\begin{array}{r}5.6 \\
15.5 \\
14.1 \\
52.1 \\
12.7\end{array}$ & 71 \\
\hline
\end{tabular}

${ }^{15}$ Forgoing boat shares has been documented in the Puerto Rican small-scale hook and line and trap fisheries (Agar and Shivlani, 2016; Agar et al., 2017). Similarly, Salazar Espinosa (2015) reports that artisanal fishermen in Chile often have their fishing income tied to their labor rather than to the provision of capital. 
noted that the income split was customary and that crew often contributed to the enterprise by bringing their own gear. Divers received a higher compensation than boat tenders because of their contribution to revenues.

The study estimated that the average owner-operator earned about $\$ 72$ per trip (\$58 median, \$8-\$235 range) whereas a crew member netted almost $\$ 61$ per trip (\$50 median, \$5-\$235 range). ${ }^{16}$ Occasionally, crew members would receive additional compensation if the trip was particularly successful. Valdés-Pizzini (1985) reports that, in the early 1980's, an owner-operator (in a 2-person operation) would earn \$90 (\$205 in today's dollars) and his boat tender would make $\$ 30$ (\$68 in today's dollars) during a good trip.

Although these latter income statistics may not be strictly comparable because they are confined to the port of Puerto Real, they may still be reflective of declining labor returns owing to the heavy exploitation of inshore grounds and stricter regulations (e.g., hookah ban, seasonal closure, 350 conch trip limit). Matos-Caraballo (2009) reports that declining queen conch stocks in the 1980's forced divers to move into deeper waters (from 4-12 to $70 \mathrm{ft}$ ).

Crew responsibilities extended beyond fishing. About 58\% of the respondents said crew members helped with various cleaning, maintenance, and repair chores. Most of these fishing related activities were unpaid. Agar et al. (2008) suggest that this unremunerated assistance arises from shared cultural values of mutual help. Only $10 \%$ of the respondents said that the crew helped finance trip-related expenses (e.g., fuel) and/or the purchase of crafts, engines, and/or gear.

\section{Crew Composition, Recruitment, and Turnover}

The composition of the crew was found to be dominated by non-kin. Boats were crewed with friends and acquaintances (63\%), family mem-

\footnotetext{
${ }^{16}$ The Puerto Rican minimum wage rate was $\$ 7.25$ per hour (Bureau of Labor Statistics, 2017b).
}

bers $(28 \%)$, or some combination of both $(10 \%)$. Crew was recruited from local or neighboring communities. While information on past crew structure is limited Valdés-Pizzini (1985) notes that, at least on the west coast of Puerto Rico, most divers owned their boat or the diving equipment (or both), whereas boat tenders were hired hands. Most of these divers grew up in fishing families, working on their family's trap and/or (deep-water snapper) vertical line operations but later transitioned to diving because of poor catches and working conditions.

There are several explanations for the prevalence of non-kin crew. One reason is that diving is a dangerous activity which favors recruitment decisions based on skill, teamwork, and compatibility rather than on kinship ties (Norr and Norr, 1974, 1978).

A second reason has to do with the dispersal and weakening of kinship ties (Symes and Frangoudes, 2001). Owner-operators reported that they fished with non-kin because many had no family members who fished. Several fishermen remarked that fishing families are increasingly discouraging their offspring from pursuing fishing because of the hardships of eking out a living. In addition, respondents noted that higher educational attainment, widening vocational aspirations, greater occupational mobility, and out-migration (to the continental United States) no longer made fishing an "occupation of choice or necessity" (Symes and Frangoudes, 2001; van Ginkel, 2001; Symes, et al.,2015). ${ }^{17} \mathrm{~A}$ number of captains stated that they did not differentiate between kin and nonkin crew because the latter were considered part of the family stressing the

\footnotetext{
${ }^{17}$ Despite high migration rates to the continental United States, remittance proceeds from Puerto Ricans tend to be lower than other comparable migrant groups (Dominicans and Mexicans). Duany (2010) argues that Puerto Ricans are less generous because recipients back home have access to public assistance (e.g., nutritional assistance, housing subsidies) and entitlement programs (e.g., Social Security, Medicare, disability, and unemployment benefits) which act as a safety net much like remittances do in the Dominican Republic and Mexico. Hence, Puerto Ricans feel less compelled to send money back home.
}

importance of affective social relations (Sonvisen et al., 2011).

Respondents reported that capable divers and boat tenders were hard to come by. About $54 \%$ of the respondents said it was difficult to recruit divers, 3\% held it was challenging, and an additional $17 \%$ stated it was easy. However, 27\% could not answer this question because they were unfamiliar with the labor market since they had long-term relationships with their non-kin crew or relied on kin. Roughly $51 \%$ of the interviewees thought it was difficult to find crew and another $23 \%$ said it was easy. However, as in the case of the question dealing with diver recruitment, almost $18 \%$ could not provide an answer.

Crew members exhibited a high degree of occupational fidelity. About $84 \%$ of respondents stated that they rarely employed new divers underlining the close-knit nature of the operation. Less than $2 \%$ of the divers surveyed stated that they employed at least one different diver on each trip. As one diver recounted, most individuals who became fishermen were born with the yearning for the fishing lifestyle. Close personal ties further cement these low turnover rates.

\section{Efficacy of the Queen Conch Seasonal Closure}

The final motivation of this study was to understand the degree to which the queen conch seasonal closure had proved useful. Fishing for queen conch is prohibited in Puerto Rico's jurisdictional waters from 1 Aug. through 31 Oct., and in the U.S. Exclusive Economic Zone year round with the exception of an area east of St. Croix, U.S. Virgin Islands. ${ }^{18}$

About $69 \%$ of the divers queried viewed the performance of the closure favorably, whereas the remaining felt its performance had either been fair or poor (Table 7). Divers who held a positive view believed that the closure had helped conch populations by allowing the stock to reproduce and grow.

\footnotetext{
${ }^{18}$ The Federal open season extends from 1 Nov.
} through 31 May. 
Table 7.-Views about the performance of the queen conch seasonal closure by coastal region.

\begin{tabular}{|c|c|c|c|c|c|c|}
\hline Variable & $\begin{array}{l}\text { East } \\
\text { coast }\end{array}$ & $\begin{array}{l}\text { North } \\
\text { coast }\end{array}$ & $\begin{array}{l}\text { South } \\
\text { coast }\end{array}$ & $\begin{array}{l}\text { West } \\
\text { coast }\end{array}$ & $\begin{array}{l}\text { Island- } \\
\text { wide }\end{array}$ & $\begin{array}{l}\text { Number of } \\
\text { respondents }\end{array}$ \\
\hline \multicolumn{7}{|c|}{$\begin{array}{l}\text { Views about the efficacy of the } \\
\text { queen conch closure (\%) }\end{array}$} \\
\hline Good & 66.7 & 71.4 & 65.2 & 72.2 & 69.1 & \\
\hline Average & 13.3 & 28.6 & 21.7 & 11.1 & 16.1 & \\
\hline Poor & 20.0 & & 13.0 & 16.7 & 14.8 & \\
\hline
\end{tabular}

Nonetheless, they felt that better policing and compliance were needed.

By contrast, divers who thought that the closure had done a fair job felt that the closure had a minimal impact (if any) on conch populations. Many of the divers who felt that the closure performed poorly believed that it initially worked but no longer was effective due to the lack of compliance and enforcement. Moreover, they questioned the science behind the need and timing of the closure and underscored significant economic hardship brought about by the 3-mo closure. These divers also called for improved surveillance and enforcement.

\section{Conclusion}

Understanding the economic and social organization of the fishery can play an important role in the choice of policy prescriptions. Aside from describing user groups that may gain or lose from the policy changes, organizational knowledge can also inform and, potentially influence, policy by discerning and mapping interrelationships, feedback loops, and cumulative processes that impact the well-being of these groups (Pollnac et al., 2006). However, within a user group responses to policy changes can be complex and highly differential since they are influenced by, among other things, household demographics, capital investment, regulatory environment, accessible economic opportunities, and reference group behavior (Acheson, 2001).

This study found that the commercial dive fishery in the Commonwealth of Puerto Rico is composed of seasoned, small-scale commodity producers, who use labor intensive and low technology capital to catch a variety of high valued species. Divers were highly dependent on fishing which made them more likely to engage in dangerous fishing practices particularly if recent landings were low. The study also suggested that the risky nature of diving, the limited availability of able crew, and the dispersal and weakening of kinship ties were important reasons behind the reliance on non-household labor.

While there are no plans to amend existing fishery management plans, the findings from this study suggest that the imposition of restrictive regulations would bring about significant hardships on certain segments of the fishery, particularly on middle-aged fishermen who exhibited high degrees of fishing dependence and occupational fidelity. Even worse, as noted by one of the reviewers, restrictive regulations may encourage riskier (e.g., multiple long dives during the open season), and even deceptive practices (e.g., night diving to evade enforcement) to offset income losses.

Finally, the study found that safety remains a besetting problem underscoring the need to improve safety at sea. Besides making concerted efforts to educate and disseminate information about the risks of diving and encouraging best practices (e.g., planning dives, checking equipment, learning about personal physical limits, resting between dives, etc.), fishery managers could improve safety at sea by requiring diving certifications (or recertifications every number of years) to participate in certain fisheries such as the queen conch fishery, for which the Commonwealth already requires a dedicated permit (or endorsement). Fishery managers should also consider collecting data on injuries, accidents, and fatalities to assess the full impact of management actions and revise them as needed.

\section{Acknowledgments}

We would like to express our gratitude to all the divers who kindly shared their time and knowledge of the fishery. Also, we would like to acknowledge the hard work of our interviewers Glenis Padilla, Edgardo Figueroa, Javier Medina, Jeiger Medina, and Francisco Soto.

We also want to thank Andy Maldonado and Fred Lentz, commercial divers, Miguel Rolón and Graciela García-Moliner from the Caribbean Fishery Management Council, Daniel Matos-Caraballo from Puerto Rico's Fisheries Research Laboratory, Ruperto Chaparro Serrano from Puerto Rico's Sea Grant Program, Bill Arnold, Matt McPherson, and Joshua Bennett of NOAA, and Walter Keithly, Louisiana State University, for their insightful comments on the manuscript. In addition, we would like to thank Maria Estevanez and Carlos Rivero for the cartographic assistance. Finally, we would like to thank Isabel Castro from the University of Miami for her tireless administrative support. Funding from the NMFS Office of Science and Technology supported this project. The views and opinions provided or implied in this manuscript are those of the authors and do not necessarily reflect the positions or policies of the NMFS, NOAA.

\section{Literature Cited}

Acheson, J. M. 1981. Anthropology of fishing. Annu. Rev. Anthropol. 10:275-316. (doi: https://doi.org/10.1146/annurev.an.10. 100181.001423).

2001. Confounding the goals of management: response of the Maine lobster industry to a trap limit. N. Am. J. Fish. Manage. 21:404-416. (doi: https://doi.org/ http://10.1577/1548-8675(2001)021<0404: CTGOMR>2.0.CO;2).

Agar, J., J. Waters, M. Valdés-Pizzini, M. Shivlani, T. Murray, J. Kirkley, and D. Suman. 2005. U.S. Caribbean fish trap fishery costs and earnings study. U.S. Dep. Commer., NOAA Tech. Memo. NMFS-SEFSC-534, 127 p.

\footnotetext{
$\longrightarrow$, $\longrightarrow$ and $\longrightarrow \overline{\text { U.S. Caribbean }}$, fish trap fishery socioeconomic study. Bull. Mar. Sci. 82(3):315-331.

and M. Shivlani. 2016. Socio-economic study of the hook and line fishery in the Commonwealth of Puerto Rico (2014). U.S. Dep. Commer., NOAA Tech. Memo. NMFSSEFSC-700, $34 \mathrm{p}$.
} 
and M. Shivlani, and D. Solis. In press. The commercial trap fishery in the Commonwealth of Puerto Rico: an economic, social and technological profile. N. Am. J. Fish. Manage.

Appeldorn, R. S. 1991. History and recent status of the Puerto Rican conch fishery. Proc. Annu. Gulf Caribb. Fish. Inst. 40:267-282. 1997. The fisheries for the queen conch, Strombus, gigas, mangrove oyster, Crassostrea rhizophorae, and other shelled mollusks of Puerto Rico. In C. L. MacKenzie, V. Burnell, A. Rosenfield, and W. L. Hobart (Editors), The history, present condition, and future of molluscan fisheries of North and Central America, and Europe, Vol. 1, Atlantic and Gulf Coasts, p. 223-234. U.S. Dep. Commer., NOAA Tech. Rep. NMFS 127.

Boncoeur J., L. Coglan, B. Le Gallic, and S. Pascoe. 2000. On the (ir)relevance of rates of return measures of economic performance to small boats. Fish. Res. 49(2):105-115. (doi: https://doi.org/10.1016/ S0165-7836(00)00209-5).

Bureau of Labor Statistics. 2017a. Metropolitan and Nonmetropolitan Area Occupational Employment and Wage Estimates. Online at https://www.bls.gov/oes/2014/may/ oes_7200002.htm\#45-0000, Accessed on 12 Jan. 2017.

2017b. Minimum Wage Laws in the States. Online at https://www.dol.gov/whd/ minwage/america.htm\# Puerto Rico, Accessed on 12 Jan. 2017.

Doeringer, P. B., P. I. Moss, and D. G. Terkla. 1986. Capitalism and kinship: do institutions matter in labor markets? Ind. Labor Relat. Rev. 40(1):48-60.

Duany, J. 2010. To send or not to send: migrant remittances in Puerto Rico, the Dominican Republic and Mexico. Ann. Am. Acad. Pol. Soc. Sci. 630:205-223.

González-Román, J. 1991. ¿Pescadores de carrucho: suicidas en potencia? Bol. Mar. 126):2-4.

Griffith, D. C., and M. Valdés-Pizzini. 2002. Fishers at work, workers at sea: a Puerto Rican journey through labor and refuge. Temple Univ. Press, Phila., Pa., 256 p.

M. Valdés-Pizzini, and C. GarcíaQuijano. 2007. Entangled communities: socioeconomic profiles of fishers, their communities, and their responses to marine protected measures in Puerto Rico. In J. J. Agar and B. Stoffle (Editors), NOAA Series on U.S. Caribbean Fishing Communities. U.S Dep. Commer., NOAA Tech. Memo. NMFS SEFSC-556, $524 \mathrm{p}$.

Guillen, J., C. Macher, M. Merzéréaud, J. Boncoeur, and O. Guyader. 2015. Effects of the share remuneration system on fisheries management targets and rent distribution. Mar. Res. Econ. 30(2):123-138. (doi: https://doi. org/10.1086/679970).

Jarvis, N. D. 1932. The fisheries of Puerto Rico. U.S. Dep. Commer., Bur. Fish. Invest. Rep. 13, $41 \mathrm{p}$.

Krueger, A. O., R. Teja, and A. Wolfe. 2015. Puerto Rico: a way forward. Gov. Develop. Bank for Puerto Rico, (avail. at http://www. bgfpr.com/documents/puertoricoawayforward.pdf). Accessed 15 Jan. 2016.

Lopez-Tristani, A., C. E. Lehner, M. A. Wilson, M. Ferrigno, L. Vaicekavicius, J. Kraemer, V. Robles, E. M. Hart, and J. J. Weber. 2004. High prevalence of dysbaric osteonecrosis among Puerto Rican seafood divers. (avail. at http://archive.rubicon-foundation.org/xmlui/ handle/123456789/1530). Accessed 25 Sept. 2015.

Matos Caraballo, D. 2009. Lessons learned from the Puerto Rico's commercial fishery, 19882008. Proc. Annu. Gulf Caribb. Fish. Inst. 61:123-129.

and J. Agar. 2011. Census of active fishermen in Puerto Rico (2008). Mar. Fish. Rev. 73(1):13-27.

and Z. Torres Rosado. 1989. Censo comprensivo de pesqueria comercial de Puerto Rico, 1988. Informe Técnico Corp. para el desarrollo y administración de los recursos marinos, lacustres y fluviales 1(3): 1-55.

NMFS. 2015. Status of stocks 2015. Annual report to Congress on the status of U.S. fisheries. U.S. Dep. Commer., NOAA, Natl. Mar. Fish. Serv., 7 p. (Avail. online at http://www. $\mathrm{nmfs}$.noaa.gov/sfa/fisheries_eco/status of_fisheries/archive/2015/2015_status_of_stocks updated.pdf).

2016. Accumulated Landings System database. U.S. Dep. Commer., NOAA, NMFS, SEFSC. https://www.sefsc.noaa.gov/ fisheries/caribbean.html.

Norr, J. L., and K. L. Noor. 1974. Environmental and technical factors influencing power in work organizations. Sociol. Work. Occup. $1(2): 219-251$ and 1978. Work organization in modern fishing. Human Organ. 37(2):163 171. (doi: https://doi.org/10.17730/humo.37. 2.2056747vv0601327).

Perez, R. 2005. The state and small-scale fisheries in Puerto Rico. Univ. Press Fla., Gainesville, $218 \mathrm{p}$.

Pollnac, R. B., S. Abbott-Jamieson, C. Smith, M. L. Miller, P. M. Clay, and D. Oles. 2006. Toward a model for fisheries social impact assessment. Mar. Fish. Rev. 68(1-4):1-18.

Salas, S., and D. Gaetner. 2004. The behavioural dynamics of fishers: management implications. Fish Fish. 5:153-167. (doi: https://doi org/10.1111/j.1467-2979.2004.00146.x).

Salazar Espinosa, C. 2015. Share contract choices and economic performance: empirical evidence from the artisanal sector in Chile. Mar Res. Econ. 30(1):71-95. (doi: https://doi. org/10.1086/679463)

Sonvisen, S. A., J. P. Johnsen, and J. Vik. 2011. The Norwegian coastal employment system: what it was and what it is. Marit. Stud. 10(1):31-56.

Suárez-Caabro, J. A. 1979. El Mar de Puerto Rico: una introducción a las pesquerías de la Isla. Rio Piedras: Edit. de la Univ. Puerto Rico, 259 p.

Symes, D., and K. Frangoudes. 2001. The social organization and reproduction of inshore fishing. In D. Symes and J. Phillipson (Editors), Inshore fisheries management. p. 159-175. Kluwer Acad. Publ., Netherl.

J. Phillipson, and P. Salmi. 2015. Europe's coastal fisheries: instability and the impacts of fisheries policy. Sociol. Rural. 55(3):245-257. (doi: https://doi.org/10.1111/ soru.12096)

Valdés-Pizzini, M. 1985. Social relations of production in Puerto de la Corona: capitalism and development in the Puerto Rican fisheries. Ph.D. thesis, State Univ. N.Y. Stony Brook, $517 \mathrm{p}$

1992. Socio-economic documentation of the Puerto Rican fishermen (divers) for the queen conch resources of Puerto Rico and the U.S. Virgin Islands fishery management plan. Prep. Caribb. Fish. Manage. Plan, 37 p.

van Ginkel, R. 2001. Inshore fishermen: cultural dimensions of a maritime occupation. In D. Symes and J. Phillipson (Editors), Inshore fisheries management, p. 177-193. Kluwer Acad. Publ., Netherl. 